\title{
Meningkatkan Hasil Belajar Siswa Pada Notasi Sigma, Barisan Dan Deret Melalui Model Pembelajaran Kooperatif Tipe Jigsaw Di Kelas XII IPA I Sekolah Menengah Atas Negeri I Muaro Jambi
}

\author{
ANCE ERIPIANA TAMBUNAN \\ Sekolah Menengah Atas Negeri 1 Muaro Jambi, Indonesia
}

\begin{abstract}
The math learning process in XII IPA SMAN 1 Muaro Jambi had been run ineffectively that had affected on unsatitissfied learning's result. Besides, the laxk of students' willing on learning were identifying through the learning motivation, learning process interaction dan students' learning readiness and the results of learning. This action reaseach purposes to explore the Jigsaw model for cooperative learning is able to to improve student's learning result pn sigma notation concepts, sequences, and series.

This study conducted in XII IPA 1 SMAN 1 Muaro Jambi in 3 phases. The result of study shows that the Jigsaw model can improve learning process whereas the first phase 20 students passed in learning, the second phase 25 students achieved the learning score, and the last past 34 students rose the learning score.
\end{abstract}

Keywords: students' learning result, Jigsaw model, history

\section{Pendahuluan}

Pendidikan merupakan usaha sengaja dilakukan guna mencerdaskan kehidupan manusia dan kelangsungan hidup suatu bangsa. Berbagai usaha telah dilakukan oleh pemerintah agar pendidikan di Indonesia memiliki mutu yang tinggi. Mutu pendidikan sangat ditentukan oleh berbagai komponen, terutama yang terlibat langsung dalam proses pendidikan yaitu kurikulum, siswa, guru dan lingkungan.

Usaha-usaha yang telah diupayakan dalam peningkatan mutu pendidikan antara lain, perbaikan kurikulum pendidikan nasional, memberikan penataran kepada guru-guru, mengadakan seminar nasional, melengkapi sarana dan prasarana sekolah. Namun kenyataannya, hingga dewasa ini mutu pendidikan di Indonesia masih rendah. 
Matematika adalah salah satu mata pelajaran yang sangat penting untuk dikuasai dengan baik oleh siswa, sebab kenyataan dalam kehidupan sehari-hari manusia tidak lepas dari peranan matematika. Namun kenyataan yang ditemukan di kalangan siswa, matematika masih menjadi momok yang sangat menakutkan dan tidak sedikit yang menganggap pelajaran matematika itu tidak menarik, membosankan bahkan membenci pelajaran matematika (Suherman, 1992).

Fakta menunjukkan bahwa kualitas pembelajaran matematika di SMA Negeri I Muaro Jambi masih rendah. Ini terlihat dari persentase jumlah siswa yang telah memenuhi nilai standar ketuntasan belajar minimum (SKBM) dan nilai rata-rata ujian semester genap tahun ajaran 2007/2008, seperti pada tabel 1.1 berikut:

Tabel 1.1 Nilai rata-rata dan persentase ketuntasan belajar siswa semester genap

\begin{tabular}{|l|l|l|l|l|l|}
\hline N & Kelas & $\begin{array}{l}\text { Jumlah } \\
\text { siswa }\end{array}$ & $\begin{array}{l}\text { Persentase } \\
\text { jumlah } \\
\text { Siswa } \\
\text { memperoleh } \\
\text { nilai } \geq 63\end{array}$ & $\begin{array}{l}\text { Persentase } \\
\text { jumlah } \\
\text { siswa } \\
\text { memperoleh } \\
\text { nilai < 63 }\end{array}$ & $\begin{array}{l}\text { Nilai } \\
\text { rata-rata }\end{array}$ \\
\hline 1. & $\begin{array}{l}\text { XII IPA } \\
\text { I }\end{array}$ & 40 & $51 \%$ & $49 \%$ & 55 \\
\hline 2. & $\begin{array}{l}\text { XII IPA } \\
\text { II }\end{array}$ & 37 & $42 \%$ & $58 \%$ & 45 \\
\hline 3. & $\begin{array}{l}\text { XII IPA } \\
\text { III }\end{array}$ & 34 & $40 \%$ & $60 \%$ & 42 \\
\hline
\end{tabular}

Sumber: SMA Negeri I Muaro Jambi

Dari tabel diatas terlihat bahwa persentase jumlah siswa yang memenuhi standar ketuntasan belajar minimum yang telah ditetapkan masih rendah. Berdasarkan fakta di atas, maka guru sebagai fasilitator, inovator dan motivator harus dapat melakukan identifikasi dan analisis terhadap berbagai kendala yang dialami oleh siswa dalam proses pembelajaran.

Menurut pengalaman dan metode yang digunakan penulis selama ini dalam proses pembelajaran di SMA Negeri I Muaro Jambi masih menerapkan metode ceramah, latihan dan penugasan. Proses pembelajaran yang kurang variatif 
Meningkatkan Hasil Belajar Siswa Pada Notasi Sigma Barisan

Dan Deret Melalui Model Pembelajaran Kooperatif Tipe Jigsaw

Di Kelas XII IPA I Sekolah Menengah Atas Negeri I Muaro Jambi

pada akhirnya membuat suasana pembelajaran menjadi monoton dan menyebabkan siswa tidak banyak berperan dan terlibat secara pasif. Mereka lebih banyak menunggu sajian yang diberikan guru daripada mencari dan menemukan sendiri pengetahuan, keterampilan serta pemahaman tentang konsep yang dipelajari.

Keberhasilan belajar siswa akan terlihat dari nilai yang dihasilkan siswa. Pernyataan ini sesuai dengan pendapat Usman bahwa aktifitas muurid sangat diperlukan dalam kegiatan belajar mengajar sehingga peserta didik yang banyak aktif, sebab peserta didik sebagai objek didik adalah yang merencanakan dan yang melaksanakan belajar sendiri. (Usman, 1999, p.21)

Kesulitan yang dialami siswa perlu diatasi, dengan melakukan suatu metode pembelajaran yang diharapkan dapat memudahkan siswa dalam pemahaman terhadap konsep materi pelajaran. Salah satu metode yang dapat mengaktifkan siswa adalah dengan menerapkan metode kerja kelompok. Dengan bekerja dalam kelompok, siswa dapat menerapkan pengalaman yamg dimilikinya dan menjelaskan pengetahuan yang dimilikinya secara terbuka kepada teman sekelompoknya.

Metode kerja kelompok yang digunakan adalah metode pembelajaran kooperatif (cooperative learning). Pembelajaran kooperatif adalah metode pembelajaran kelompok, seperti diungkapkan oleh Slavin "pembelajaran kooperatif mengarah kepada metode pembelajaran dimana siswa belajar bersama di dalam kelompok kecil untuk saling membantu dalam belajar”. (Slavin. R, 2005, p.32)

Salah satu tipe pembelajaran kooperatif adalah pebelajaran tipe jigsaw. Pembelajaran jigsaw ini dikembangkan dan diujicobakan oleh Elliot Aronson bersama teman-temannya tahun 1978 di University of Texas. (Slavin. R, 2005, p.32) Pada pembelajaran tipe jigsaw, siswa dibagi kedalam beberapa kelompok kecil yang beranggotakan 4-6 orang secara heterogen.

Berdasarkan uraian di atas, penulis ingin melakukan penelitian tindakan kelas tentang hasil belajar siswa pada pokok bahasan Notasi Sigma, Barisan dan Deret dengan menggunakan model pembelajaran kooperatif tipe jigsaw di kelas 
XII IPA I SMA Negeri I Muara Jambi dengan judul "Meningkatkan Hasil Belajar Siswa Pada Notasi Sigma, Barisan dan Deret Melalui Model Pembelajaran Kooperatif tipe Jigsaw Di Kelas XII IPA I SMA Negeri I Muara Jambi".

\section{Kajian Pustaka}

\section{Belajar dan Pembelajaran}

Menurut pengertian secara psikologis, belajar merupakan suatu proses perubahan yaitu perubahan tingkah laku sebagai hasil interaksi dengan lingkungannya dalam memenuhi kebutuhan hidup. Sudjana (1996) berpendapat, belajar adalah suatu proses yang ditandai dengan adanya perubahan pada diri seseorang, perubahan sebagai hasil proses belajar dapat ditunjukkan dalam berbagai bentuk seperti perubahan pengetahuan, pemahaman, sikap dan tingkah laku, keterampilan, kecakapan, kebiasaan serta perubahan aspek-aspek yang ada pada individu yang belajar. (Sudjana. N, 1988, p.3) Selanjutnya Hamalik dalam Jihad dan Haris menjelaskan bahwa belajar adalah suatu proses perubahan tingkah laku individu melalui interaksi dengan lingkungannya. (Jihad, A., \& Haris, A, 2008, p.2)

Menurut Jihad dan Haris, belajar adalah kegiatan berproses dan merupakan unsur yang sangat fundamental dalam penyelenggaraan jenis dan jenjang pendidikan, hal ini berarti keberhasilan pencapaian tujuan pendidikan sangat tergantung pada keberhasilan proses belajar siswa di sekolah dan lingkungan sekitarnya. (Jihad, A., \& Haris, A, 2008, p.2) Syah dalam Jihad dan Haris menyatakan "Pada dasarnya belajar merupakan tahapan perubahan perilaku siswa yang relatif poisitif dan mantap sebagai hasil interaksi dengan lingkungan yang melibatkan proses kognitif”. (Jihad, A., \& Haris, A, 2008, p.2)

Dari pendapat di atas dapat dikatakan bahwa perbuatan belajar terjadi karena interaksi seseorang dengan lingkungannya yang akan menghasilkan suatu perubahan tingkah laku pada berbagai aspek, diantaranya pengetahuan, sikap dan keterampilan. 


\section{Pembelajaran Kooperatif}

Pembelajaran merupakan strategi belajar dengan sejumlah siswa sebagai anggota kelompok kecil yang tingkat kemampuannya berbeda. (Isjoni, 2007, p.12) Dengan menyelesaikan tugas kelompoknya, setiap siswa anggota kelompok harus saling bekerja sama dan saling membantu untuk memahami materi pelajaran. Menurut Slavin dalam Isjoni pembelajaran kooperatif dalah suatu model pembelajaran dimana siswa belajar dalam kelompok-kelompok kecil secara kolaboratif yang anggotanya 4-6 orang dengan struktur kelompok heterogen. (Isjoni, 2007, p.12)

Menurut Isjoni (2007: 20) ciri-ciri pembelajaran kooperatif adalah: (Isjoni, 2007, p.20)

1. Setiap anggota memiliki peran

2. Terjadi interaksi langsung diantara siswa

3. Setiap anggota kelompok bertanggung jawab atas belajarnya dan juga teman- teman sekelompoknya

4. Guru membantu mengembangkan keterampilan-keterampilan interpersonal kelompok

5. Guru hanya berinteraksi dengan kelompok saat diperlukan.

Dari pendapat diatas dapat dikatakan bahwa pembelajaran kooperatif merupakan pembelajaran secara kelompok. Siswa akan bekerja sama di dalam kelompoknya untuk mempelajari suatu materi dan akan mendapatkan pengalaman individu maupun kelompok. Setiap kelompok biasanya terdiri dari siswa dengan kemampuan yang berbeda dan jenis kelamin yang berbeda. Semua anggota kelompok akan saling bekerja sama dan saling membantu untuk mempelajari suatu materi, melengkapi tugas-tugas serta menyelesaikan suatu masalah. Keberhasilan seseorang adalah adalah keberhasilan kelompok, sebaliknya kegagalan seseorang adalah kegagalan kelompok. Sedangkan, ntuk itu kelompok yang berhasil akan diberi penghargaan dan penguatan oleh guru.

\section{Pembelajaran Kooperatif Tipe Jigsaw}

Jigsaw adalah satu model pembelajaran kooperatif yang teknik pelaksanaannya dimulai dari pembentukan kelompok yang disusun oleh guru agar 
siswa tidak memilih-milih teman yang disenangi saja, jadi sifatnya heterogen. (Alma, 2008, p.84) Menurut Isjoni pembelajaran kooperatif tipe jigsaw merupakan salah satu tipe pembelajaran kooperatif yang mendorong siswaaktif dan saling membantu dalam meenguasai materi pelajaran untuk mencapai prestasi yang maksimal. (Isjoni, 2007, p.54)

Jumlah siswa yang bekerja sama dalam masing-masing kelompok harus dibatasi, agar kelompok-kelompok yang terbentuk dapat bekerja sama secara efektif, karena suatu ukuran kelompok mempengaruhi kemampuan produktifitasnya. Jumlah yang paling tepat menurut Slavin dalam Isjoni adalah 46 orang, dikarenakan kelompok yang beranggotakan 4-6 orang lebih sepaham dalam menyelesaikan suatu permasalahan dibandingkan dengan kelompok yang beranggotakan 2-4 orang. (Isjoni, 2007, p.55)

Menurut Isjoni dalam model belajar ini terdapat tahap-tahap dalam penyelenggaraannya, yaitu: (Isjoni, 2007, p.55)

1. Siswa dikelompokkan dakambentuk kelompok-kelompok kecil berdasarkan pertimbangan tertentu

2. Setiap anggota kelompok diitugaskan mempelajari materi tertentu, perwakilan dari kelompok masing-masing bertemu dengan anggota dari kelompok lain yang mempelajari materi yang sama kemudian mempelajari dan memahami setiap masalah dijumpai

3. Setelah masing-masing perwakilan kelompok dapat menguasai materi yang ditugaskan, kembali ke kelompok semula

4. Masing-masing anggota kelompok saling menjelaskan pada teman sekelompoknya sehingga teman sekelompoknya dapat memahami materi yang dikuasai

5. Siswa diberi tes/kuis untuk mengetahui apakah siswa sudah dapat memahami suatu materi.

\section{Hasil Belajar}

Hasil belajar merupakan sesuatu yang diperoleh, dikuasai atau dimiliki siswa setelah proses pembelajaran berlangsung. Hasil belajar dapat digunakan untuk melihat apakah seseorang telah melakukan proses belajar. Bagaimana 
Meningkatkan Hasil Belajar Siswa Pada Notasi Sigma Barisan

Dan Deret Melalui Model Pembelajaran Kooperatif Tipe Jigsaw

Di Kelas XII IPA I Sekolah Menengah Atas Negeri I Muaro Jambi

seseorang melakukan proses belajar yang efektif akan menjadikan hasil belajar yang lebih berarti dan lebih bermakna.

Usman dalam Jihad dan Haris menyatakan bahwa hasil belajar yang dicapai oleh siswa sangat erat kaitannya dengan rumusan tujuan pembelajaran yang direncanakan guru sebelumnya yang dikelompokkan kedalam tiga kategori, yakni domain kognitif, afektif dan psikomotor. (Jihad, A., \& Haris, A, 2008, p.16) Arikunto menyatakan, tujuan penilaian hasil belajar adalah untuk mengetahui siswa-siswa mana yang berhak melanjutkan pelajaran karena sudah berhasil menguasai materi dan apakah metode mengajar yang digunakan sudah tepat atau belum. (Arikunto, 2008, p.16)

\section{Hubungan antara Pembelajaran Tipe Jigsaw dengan Hasil Belajar}

Joice dan Well dalam Jihad dan Haris menyatakan bahwa mengajar membantu siswa memperoleh informasi, ide, keterampilan, nilai, cara berfikir, sarana untuk mengekspresikan dirinya, dan cara-cara belajar bagaimana belajar. (Jihad, A., \& Haris, A, 2008, p.16) Menurut Alvin W. Howard dalam Haris mengajar adalah suatu aktivitas untuk mencoba menolong, membimbing seseorang untuk mendapatkan, mengubah atau mengembangkan skill, attitude ideals (cita-cita), appreciations (penghargaan) dan knowledge (pengetahuan).

Berdasarkan penjelasan di atas tentang pengertian mengajar, maka dapat disimpulkan bahwa mengajar mencakup empat pokok,yaitu :

a. Mangajar adalah mengorganisasi hal-hal yang berhubungan dengan belajar

b. Mengaktifkan siswa untuk mencapai tujuan pendidikan

c. Menyampaikan dan mengembangkan ilmu pengetahuan

d. Membimbing dan membantu siswa mencapai kedewasaan.

Pembelajaran jigsaw merupakan salah satu model pembelajaran kooperatif. Tujuan dari pembelajaran jigsaw adalah:

a. Menyajikan metode alternative disamping ceramah dan membaca

b. Mengkaji ketergantungan positif dalam menyampaikan dan menerima informasi diantara anggota kelompok untuk mendorong kedewasaan berfikir

c. Menyediakan kesempatan berlatih berbicara dan mendengarkan untuk melatih kondisi siswa dalam menyampaikan informasi. 
Dengan demikian, pembelajaran jigsaw memberikan kesempatan yang besar bagi siswa untuk mengembangkan diri sesuai kemampuan, mmemupuk rasa tanggung jawab dan keberanian dalam menyampaikan setiap informasi yang diketahuinya. Hal ini menunjukkan bahwa siswa terlibat aktif dalam pembelajaran, ini menimbulkan motivasi dalam diri siswa untuk giat belajar. Jika dalam diri siswa telah terbentuk motivasi intrinsik, maka siswa akan rajin belajar tanpa paksaan dari orang lain.

\section{Tinjauan Materi Notasi Sigma, Deret, dan Baris Notasi Sigma}

Salah satu cara untuk menulis jumlah dari suatu barisan bilangan adalah dengan menggunakan symbol $\Sigma$ (baca sigma), yaitu salah satu huruf kapital Yunani yang berarti jumlah. Secara umum ditulis :

n

$\Sigma \mathrm{a}_{\mathrm{i}}=\mathrm{a}_{1}+\mathrm{a}_{2}+\mathrm{a}_{3}+\ldots .+\mathrm{a}_{\mathrm{n}}$, dimana $\mathrm{i}=1$ disebut batas bawah dan $\mathrm{n}$ disebut batas atas.

$\mathrm{i}=1$

\section{Sifat-sifat Notasi Sigma}

$\mathrm{n}$

1. $\Sigma \mathrm{u}_{\mathrm{i}}=\mathrm{u}_{1}+\mathrm{u}_{2}+\mathrm{u}_{3}+\ldots+\mathrm{u}_{\mathrm{n}}$, $\mathrm{i}=1$

$\mathrm{n} \quad \mathrm{n}$

2. $\Sigma \mathrm{u}_{\mathrm{i}}=\Sigma \mathrm{u}_{\mathrm{j}}$

$\mathrm{i}=1 \quad \mathrm{j}=1$

$\mathrm{n}$

3. $\Sigma \mathrm{C}=\mathrm{C}$, dimana $\mathrm{c}$ adalah suatu konstanta

$\mathrm{i}=1$

$\mathrm{n} \quad \mathrm{n}$

4. $\Sigma \mathrm{Cu}_{\mathrm{i}}=\mathrm{C} \Sigma \mathrm{u}_{\mathrm{i}}$, dimana c adalah suatu konstanta

$\mathrm{i}=1 \quad \mathrm{j}=1$

n n n

5. $\Sigma\left(\mathrm{u}_{\mathrm{i}} \pm \mathrm{vi}_{\mathrm{i}}\right)=\Sigma \mathrm{u}_{\mathrm{i}} \pm \Sigma \mathrm{v}_{\mathrm{i}}$

$i=1 \quad i=1 \quad i=1$

n $\quad$ n $\quad n$ n

$6 \quad \Sigma\left(\mathrm{u}_{\mathrm{i}} \pm \mathrm{v}_{\mathrm{i}}\right)^{2}=\Sigma \mathrm{u}_{\mathrm{i}}^{2} \pm 2 \Sigma \mathrm{u}_{\mathrm{i}} \mathrm{v}_{\mathrm{i}}+\Sigma \mathrm{v}_{\mathrm{i}}^{2}$ $\mathrm{i}=1 \quad \mathrm{i}=1 \quad \mathrm{i}=1 \quad \mathrm{i}=1$

n m m

7. $\Sigma \mathrm{u}_{\mathrm{i}}+\Sigma \mathrm{u}_{\mathrm{i}}=\Sigma \mathrm{u}_{\mathrm{i}}$

$\mathrm{i}=1 \quad \mathrm{i}=\mathrm{n}+1 \quad \mathrm{i}=1$

$\mathrm{n} \quad \mathrm{n}-1 \quad \mathrm{n}+1$

8. $\Sigma \mathrm{u}_{\mathrm{i}}+\Sigma \mathrm{u}_{\mathrm{i}}+1=\Sigma \mathrm{u}_{\mathrm{i}}-1$

$\mathrm{i}=1 \quad \mathrm{i}=0 \quad \mathrm{i}=2$ 
Meningkatkan Hasil Belajar Siswa Pada Notasi Sigma Barisan

Dan Deret Melalui Model Pembelajaran Kooperatif Tipe Jigsaw

Di Kelas XII IPA I Sekolah Menengah Atas Negeri I Muaro Jambi

\section{$\mathrm{n}$}

9. $\Sigma \mathrm{u}_{\mathrm{i}}=\mathrm{u}_{\mathrm{n}}$, dimana $\mathrm{n}=1,2,3, \ldots, \mathrm{n}$ yang merupakan elemen bilangan asli. $i=1$

\section{Induksi Matematika}

Induksi matematika adalah pembuktian rumus (teorema) yang benar untuk setiap bilangan asli.Prinsip induksi matematika adalah sebagai berikut. Misalkan $\mathrm{P}(\mathrm{n})$ menyatakan rumus untuk setiap bilangan asli n. Jika :

1. $P(n)$ benar untuk $n=1$

2. Jika diasumsikanbahwa $P(n)$ benar untuk $n=k$ dan ditunjukkan bahwa $P(n)$ benar untuk $\mathrm{n}=\mathrm{k}+1$, maka $\mathrm{P}(\mathrm{n})$ benar untuk setiap bilangan asli.

\section{Barisan dan Deret}

\section{Barisan dan Deret Aritmetika}

Barisan Aritmetika

Barisan aritmetika atau barisan hitung adalah suatu barisan bilangan, dengan setiap dua suku yang berurutan memiliki selisih tetap (konstan). Jika suku pertama dari barisan aritmetika $\left(\mathrm{U}_{1}\right)$ dinotasikan dengan a dan selisih antara dua suku berurutan disebut beda yang dinotasikan dengan $\mathrm{b}$, suku-suku barisan aritmetika dituliskan : $a, a+b, a+2 b,+\ldots+a+(n-1) b, \ldots \ldots$ Barisan ini dinamakan barisan aritmetika baku dengan rumus umum suku ke-n sebagai berikut $: U n=a+(n-1) b$.

\section{Deret Aritmetika}

Jumlah seluruh suku-suku dari barisan aritmetika disebut deret aritmetika. Jika $a, a+b, a+2 b+\ldots .+a+(n-1) b$ adalah barisan aritmetika baku maka $a+a+2 b+a+3 b+\ldots+a+(n-1) b$ disebut deret aritmetika baku, Jumlah n suku pertama deret aritmetika dinotasikan dengan $S_{n}$, sehingga:

$$
\mathrm{S}_{\mathrm{n}}=\mathrm{a}+(\mathrm{a}+2 \mathrm{~b})+\ldots+(\mathrm{n}-1) \mathrm{b}=\sum_{\mathrm{k}=1}^{\mathrm{n}}(\mathrm{a}+(\mathrm{k}-1) \mathrm{b}
$$

Rumus jumlah n suku dapat ditentukan sebagai berikut :

$S_{\mathrm{n}}=1 / 2 \mathrm{n}(2 \mathrm{a}+(\mathrm{n}-1) \mathrm{b})$ atau $S_{\mathrm{n}}=1 / 2 \mathrm{n}\left(\mathrm{a}+\mathrm{U}_{\mathrm{n}}\right)$

Dimana : $\mathrm{S}_{\mathrm{n}}=$ jumlah $\mathrm{n}$ suku

$$
\begin{aligned}
& \mathrm{a}=\text { suku pertama } \\
& \mathrm{b}=\text { beda }
\end{aligned}
$$


$\mathrm{n}$ = banyak suku

\section{Barisan dan Deret Geometri}

\section{Barisan Geometri}

Barisan geometri atau barisan ukur adalah suatu barisan bilangan yang setiap sukunya diperoleh dengan cara mengalikan suku di depannya dengan bilangan yang tetap (konstan). Bilangan yang tetap ini disebut pembanding (rasio) yang dinotasikan dengan r. Secara umum dikatakan sebagai berikut:

Suatu barisan $\mathrm{U}_{1}, \mathrm{U}_{2}, \mathrm{U}_{3}, \ldots, \mathrm{U}_{\mathrm{n}}$ disebut barisan geometri apabila berlaku

\section{$\mathrm{U}_{\mathrm{n}}$} $=$

Apabila suku pertama $\left(\mathrm{U}_{1}\right)$ dari barisan geometri a, ar, $\operatorname{ar}^{2}, \ldots, \operatorname{ar}^{\mathrm{n}-1}, \ldots$. Barisan ini disebut barisan geometri baku. Rumus umum suku ke - $\mathrm{n}$ barisan geometri adalah

$$
\begin{aligned}
\mathrm{U}_{\mathrm{n}}=\operatorname{ar}{ }^{\mathrm{n}-1} \text {, dimana : } \mathrm{U}_{\mathrm{n}} & =\text { suku ke }-\mathrm{n} \\
\mathrm{a} & =\text { suku pertama } \\
\mathrm{r} & =\text { rasio } \\
\mathrm{n} & =\text { banyak suku. }
\end{aligned}
$$

Deret Geometri

Deret geometri atau deret ukur adalah suatu deret yang diperoleh dengan menjumlahkan suku suku barisan geometri. Jumlah $\mathrm{n}$ suku pertama dari deret geometri dinyatakan dengan $\mathrm{S}_{\mathrm{n}}$, sehingga :

$$
\mathrm{S}_{\mathrm{n}}=\mathrm{a}+\mathrm{ar}+\mathrm{ar}^{2}+\ldots+\operatorname{ar}^{\mathrm{n}-1}=\Sigma \mathrm{ar}^{\mathrm{k}-1} \text {. Rumus jumlah } \mathrm{n} \text { suku }
$$
pertama dari deret

$$
\mathrm{k}=1
$$

$$
\begin{aligned}
& \text { geometri adalah } S_{n}=\frac{a\left(1-r^{n}\right)}{1-r} \text { - } \\
& \mathrm{S}_{\mathrm{n}}=\frac{\mathrm{a}\left(\mathrm{r}^{\mathrm{n}}-1\right)}{\mathrm{r}-1}
\end{aligned}
$$

Deret Geometri Tak Berhingga

Misalkan r adalah rasio suatu barisan geometri, barisan itu disebut : 
a. Barisan divergen (berhingga) jika $|\mathrm{r}|>1$, artinya $\mathrm{r}\langle-1$ atau $\mathrm{r}>1$

b. Barisan konvergen (tak berhingga) jika $|\mathrm{r}|<$, artinya $-1<\mathrm{r}<1$

Pada deret konvergen, jumlah suku-sukunya tidak akan melebihi suatu harga tertentu, tetapi terus menerus mendekati harga tersebut. Harga tertentu itu disebut jumlah tak berhingga suku yang dinotasikan dengan $\mathbf{S}_{\infty}$. Harga $\mathbf{S}_{\infty}$ merupakan harga pendekatan (limit) jumlah semua suku $\left(S_{n}\right)$ untuk $n$ mendekati tak berhingga. Rumus jumlah tak berhingga suku dari deret geometri yang konvergen adalah:

$$
\mathrm{S}_{\infty}=\frac{\mathrm{a}}{1-\mathrm{r}}
$$

\section{Penggunaan Barisan dan Deret}

Dalam kehidupan sehari-hari banyak masalah yang dapat diselesaikan dengan menggunakan kaidah barisan maupun deret, misalnya perhitungan bunga bank, perhitungan kenaikan produksi dan laba suatu usaha. Untuk menyelesaikan persoalan tersebut terlebih dahulu kita tentukan apakah barisan aritmetika, barisan geometri, deret aritmetika atau deret geometri. Kemudian kita selesaikan dengan rumus yang berlaku.

\section{Metode}

Penelitian dilakukan di kelas XII IPA I SMA Negeri I Muara Jambi dengan jumlah siswa 39 orang yang terdiiri dari 10 orang laki-laki dan 29 orang perempuan.yang dibagi dalam 8 kelompok belajar dengan anggota dari setiap kelompok berjumlah 5 orang. Penelitian ini dilaksanakan mulai tanggal 12 Januari 2019 hingga tanggal 7 Pebruari 2019.

\section{Prosedur Penelitian}

1. Perencanaan

Adapun kegiatan yang dilaksanakan dalam tahap perencanaan ini adalah:

a. Membuat skenario pembelajaran

Skenario pembelajaran yang akan dilaksanakan pada PTK ini dalam tiap siklus.

b. Membuat lembar observasi: untuk melihat bagaimana kondisi belajar mengajar di kelas ketika kegiatan pembelajaran berlangsung. 
Lembar observasi yang digunakan pada penelitian ini di setiap siklus, seperti pada tabel 1 berikut.

Tabel 1 Lembar observasi kegiatan siswa

\begin{tabular}{|c|c|c|c|c|c|}
\hline No. & Aspek yang diamati & $\begin{array}{l}\text { Baik } \\
\text { sekali }\end{array}$ & Baik & Cukup & Kurang \\
\hline $\begin{array}{l}5 . \\
6 . \\
7 . \\
8 .\end{array}$ & $\begin{array}{l}\text { Antusias siswa dalam mengikuti KBM } \\
\text { Kelancaran mengemukakan ide dalam } \\
\text { memecahkan masalah } \\
\text { Keaktifan siswa dalam diskusi } \\
\text { Kemampuan siswa dalam } \\
\text { menghimpun hasil diskusi } \\
\text { Ketelitian dalam menghimpun hasil } \\
\text { diskusi } \\
\text { Keaktifan dalam bertanya } \\
\text { Keaktifan siswa dalam mencari } \\
\text { sumber belajar } \\
\text { Kelancaran siswa dalam menjawab } \\
\text { pertanyaan }\end{array}$ & & & & \\
\hline
\end{tabular}

(Sumber : Penelitian Tindakan Kelas, Aqib dkk)

Kriteria penilaian :
Baik sekali
: $86-100$
Baik
: $71-85$
Cukup
: $60-70$

Kurang

: di bawah 60

a. Membuat alat bantu mengajar

Alat Bantu mengajar berupa rencana program pengajaran (RPP) dan buku sumber pembelajaran.

b. Membuat lembar evaluasi

Lembar evaluasi tes tertulis dalam bentuk essay tes. 
Meningkatkan Hasil Belajar Siswa Pada Notasi Sigma Barisan

Dan Deret Melalui Model Pembelajaran Kooperatif Tipe Jigsaw

Di Kelas XII IPA I Sekolah Menengah Atas Negeri I Muaro Jambi

2. Pelaksanaan tindakan

Pada tahap ini dilaksanakan tindakan untuk menerapkan skenario yang telah disusun sebelumnya kedalam tindakan konkrit.

3. Observasi dan Evaluasi

Observasi dilaksanakan pada saat tindakan pembelajaran berlangsung dengan menggunakan lembar observasi yang telah dirancang pada perencanaan. Sedangkan evaluasi dilaksanakan pada akhir setiap siklus.

4. Refleksi dan Revisi

Hasil yang diperoleh dalam tahap observasi akan dianalisis untuk diolah dengan metode yang telah disiapkan. Dari hasil pengolahan ini akan dijadikan bahan bahan refleksi untuk mengambil kesimpulan apakah pelaksanaan tindakan dapat dilanjutkan pada siklus berikutnya dan hal-hal apa saja yang perlu diperbaiki.

Data yang diperoleh yaitu data dari hasil evaluasi siswa dari siklus pertama dianalisis untuk melihat hasil yang diperoleh siswa sebagai dasar untuk melaksanakan siklus kedua dan seterusnya. Untuk memperoleh nilai siswa digunakan skala penilaian 10-100 dan pengolahan nilai menggunakan rumus:

Skor yang diperoleh siswa

Nilai siswa $=$--------------------- X 100

Nilai rata-rata kelas ditentukan dengan menggunakan rumus :

$$
\bar{X}=\frac{\sum x_{i}}{N} \text {---- } X 100, \text { dimana }
$$

$\overline{\mathrm{X}} \quad=$ nilai rata-rata

$\sum \mathrm{x}_{\mathrm{i}}=$ jumlah data

$\mathrm{N} \quad=$ banyak data

Untuk menentukan persentase ketuntasan belajar siswa secara klasikal menggunakan rumus : 


$$
\begin{aligned}
& \text { Jumlah siswa yang tuntas }
\end{aligned}
$$

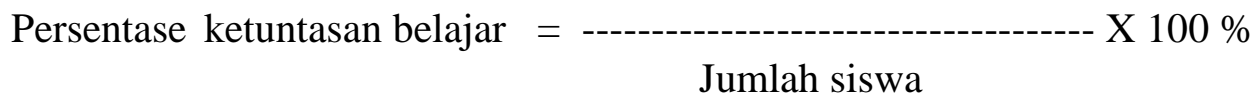

Indikator keberhasilan dalam PTK ini adalah :

1. Persentase siswa yang telah memenuhi nilai kriteria ketuntasan minimum yaitu 63 mencapai atau lebih dari $85 \%$.

2. Peningkatan rata-rata kelas dari hasil belajar siswa pada pembelajaran Notasi Sigma, Barisan dan Deret setiap siklus.

\section{Hasil}

\section{Kegiatan Pratindakan}

Pada pelaksanaan pratindakan, guru melaksanakan kegiatan pembelajaran dengan metode ceramah dan latihan. Proses pembelajaran yang dilaksanakan dimulai dengan penjelasan tujuan pembelajaran yang akan dicapai, motivasi, pemahaman konsep dengan ceramah, penerapan melalui latihan, bimbingan untuk merangkum materi dan pemberian tugas serta pada akhir materi pokok dibarikan evaluasi.

Hasil observasi terhadap kegiatan pembelajaran siswa tterlihat pada tabel 2 berikut.

Tabel 2. Hasil observasi kegiatan siswa pada pratindakan

\begin{tabular}{|c|c|c|}
\hline No. & Aspek yang diamati & Persentase jumlah siswa \\
\hline 1. & Antusias siswa dalam mengikuti KBM & 55 \\
\hline 2. & Kelancaran mengemukakan ide & 31 \\
\hline 3. & memecahkan masalah & - \\
\hline 4. & Keaktifan siswa dalam diskusi & - \\
\hline 5. & Kemampuan siswa dalam menghimpun hasil & - \\
\hline 6 & diskusi & 20 \\
\hline 7 & Ketelitian dalam menghimpun hasil diskusi & 52 \\
\hline 8 & Keaktifan dalam bertanya & 37 \\
\hline & $\begin{array}{l}\text { Keaktifan siswa dalam mencari sumber belajar } \\
\text { Kelancaran siswa dalam menjawab pertanyaan }\end{array}$ & \\
\hline
\end{tabular}

Tabel 1 di atas menunjukkan:

1. Antusias siswa dalam belajar masih kurang karena metode pembelajaran ceramah menyebabkan siswa hanya menunggu sajian dari guru sehingga motivasi siswa untuk belajar kurang. 
Meningkatkan Hasil Belajar Siswa Pada Notasi Sigma Barisan Dan Deret Melalui Model Pembelajaran Kooperatif Tipe Jigsaw Di Kelas XII IPA I Sekolah Menengah Atas Negeri I Muaro Jambi

2. Kelancaran mengemukakan ide dalam memecahkan masalah masih minim karena siswa yang tidak memmahami konsep pelajaran tidak termotivasi untuk dapat menjawab soal-soal latihan.

3. Keaktifan dalam bertanya masih kurang, masih didominasi siswa yang mampu memahami materi pelajaran karena siswa tidak mau tertantang untuk dapat memahami materi pelajaran dan menyelesaikan soal-soal.

4. Kelancaran siswa dalam menjawab pertanyaan masih minim, masih didominasi anak yang memahami konsep saja, karena sebagian besar siswa hanya menunggu jawaban dari guru.

Hasil evaluasi siswa pada kegiatan pratindakan diperoleh gambaran ketuntasan belajar siswa seperti pada tabel 3 berikut:

Tabel 3 Hasil belajar siswa pada pratindakan

\begin{tabular}{|c|c|c|c|}
\hline No. & Nilai yang diperoleh & Banyak siswa & Jumlah nilai \\
\hline 1. & 80 & 2 & 160 \\
\hline 2. & 75 & 3 & 225 \\
\hline 3. & 70 & 3 & 210 \\
\hline 4. & 65 & 4 & 260 \\
\hline 5. & 63 & 3 & 189 \\
\hline 6 & 60 & 7 & 420 \\
\hline  & 50 & 8 & 400 \\
\hline 8. & 48 & 5 & 240 \\
\hline $\begin{array}{l}0 . \\
9 .\end{array}$ & 40 & 4 & 160 \\
\hline & Jumlah siswa & 39 & \\
\hline & Jumlah nilai & & 2264 \\
\hline & Rata-rata nilai & & 58,05 \\
\hline & Jumlah siswa yang tuntas & 15 & \\
\hline & $\%$ Ketuntasan siswa & 38,46 & \\
\hline
\end{tabular}

Pada tabel di atas terlihat bahwa pada kegiatan pembelajaran pratindakan, dari 39 siswa nilai rata-rata siswa 58,05, jumlah siswa yang tuntas belajar 15 Orang dan ketuntasan secara klasikal mencapai 38,46\%. Hal ini berarti banyak siswa yang telah tuntas belajar masih rendah dan perlu dianalisa untuk mengetahui permasalahan yang dihadapi siswa untuk diadakan perbaikan. 


\section{Siklus I}

1) Pelaksanaan

Pada siklus I model pembelajaran tipe jigsaw dilaksanakan dengan memperhatikan hal-hal sebagai berikut :

1. Pengelompokan siswa didasarkan pada hasil evaluasi kegiaatan pratindakan, yang dikelompokkan secara heterogen.

2. Memantau secara penuh kegiatan pembelajaran dan memberikan bantuan kepada siswa yang mengalami kesulitan.

3. Memberikan motivasi agar siswa dapat bekerja secara aktif.

4. Melaksanakan evaluasi pada akhir siklus I.

2) Hasil Observasi dan Hasil Belajar

Pada siklus I dengan kehadiran $100 \%$, dari 39 siswa Hasil observasi pada siklus I terlihat pada tabel 4 dan hasil evaluasi terlihat pada tabel 5 berikut.

Tabel 4. Hasil observasi kegiatan belajar siswa pada siklus I

\begin{tabular}{|c|c|c|}
\hline No. & Aspek yang diamati & $\begin{array}{l}\text { Persentase jumlah } \\
\text { siswa }\end{array}$ \\
\hline 1. & Antusias siswa dalam mengikuti KBM & 59 \\
\hline 2. & Kelancaran mengemukakan & 55 \\
\hline 3. & memecahkan masalah & 52 \\
\hline 4. & Keaktifan siswa dalam diskusi & 65 \\
\hline 5. & Kemampuan siswa dalam menghimpun hasil & 50 \\
\hline 6. & diskusi & 46 \\
\hline 7. & Ketelitian dalam menghimpun hasil diskusi & 60 \\
\hline 8. & $\begin{array}{l}\text { Keaktifan dalam bertanya } \\
\text { Keaktifan siswa dalam mencari sumber belajar } \\
\text { Kelancaran siswa dalam menjawab pertanyaan }\end{array}$ & 44 \\
\hline
\end{tabular}


Tabel 5. Hasil evaluasi siswa pada siklus I

\begin{tabular}{|l|l|l|l|}
\hline No. & Nilai yang diperoleh & Banyak siswa & Jumlah nilai \\
\hline 1. & 85 & 1 & 85 \\
2. & 83 & 1 & 83 \\
3. & 80 & 1 & 80 \\
4. & 78 & 1 & 78 \\
5. & 70 & 2 & 140 \\
6. & 69 & 1 & 69 \\
7. & 67 & 2 & 134 \\
8. & 65 & 2 & 130 \\
9. & 63 & 3 & 189 \\
10. & 60 & 5 & 300 \\
11. & 55 & 4 & 220 \\
12. & 54 & 3 & 162 \\
13. & 50 & 5 & 250 \\
14. & 45 & 5 & 90 \\
15. & 40 & 3 & 120 \\
\hline \multirow{2}{*}{} & Jumlah siswa & 39 & \\
\cline { 2 - 4 } & Jumlah nilai & & 2268 \\
\cline { 2 - 4 } & Rata-rata nilai & & \\
\cline { 2 - 4 } & Banyak siswa yang tuntas & 14 & \\
\cline { 2 - 4 } & \% ketuntasan & 35,89 & \\
\hline
\end{tabular}

Pada siklus I terjadi kenaikan nilai rata-rata secara klasikal menjadi 58,15,

akan tetapi jumlah siswa yang tuntas belajar mengalami penurunan menjadi 14 orang yang mencapai 35,89\% dari jumlah seluruh siswa.

3) Analisis dan Refleksi siklus I

Berdasarkan data yang diperoleh dari hasil observasi dan hasil evaluasi siswa pada siklus I, kegiatan pembelajaran dengan menerapkan model pembelajaran tipe jigsaw belum menunjukkan hasil yang memuaskan. Hal ini terjadi karena :

1. Antusias siswa dalam kegiatan pembelajaran masih kurang, karena siswa masih belum memahami model pembelajaran kooperatif tipe jigsaw.

2. Jumlah siswa yang mengemukakan ide dalam memecahkan masalah dan siswa yang aktif dalam diskusi masih didominasi siswa tertentu, karena masih banyak siswa terbawa situasi kegiatan pembelajaran metode ceramah. 
3. Jumlah siswa yang dapat menghimpun diskusi dan teliti dalam menghimpun diskusi masih kurang, karena sebagian besar siswa masih memberikan tanggung jawab kepada siswa yang mau bekerja saja.

4. Keaktifan siswa dalam bertanya masih kurang, karena masih banyak siswa belum termotivasi untuk dapat menguasai materi.

5. Masih banyak siswa yang tidak mau mmencari sumber belajar, karena hanya mengharapkan guru sebagai sumber belajar bagi mereka.

6. Siswa yang menjawab pertanyaan masih didominasi oleh siswa yang menguasai materi, karena siswa tidak mau tertantang untuk dapat memahami konsep.

\section{Siklus II}

1) Pelaksanaan

Berdasarkan permasalahan yang ditemukan pada siklus I maka langkahlangkah pelaksanaan siklus II sebagai berikut:

1. Pengelompokan siswa didasarkan pada hasil evaluasi siklus I, yang dikelompokkan secara heterogen.

2. Pemberian materi pembelajaran secara garis besar untuk membantu siswa memahami konsep notasi sigma, cara penulisan deret aritmetika dan geometri dengan notasi sigma.

3. Motivasi dilakukan secara kontinu agar siswa dapat aktif dalam kegiatan pembelajaran.

4. Pelaksanaan observasi selama kegiatan pembelajaran berlangsung.

5. Pada akhir siklus II diadakan evaluasi untuk mengukur hasil belajar siswa.

2) Hasil observasi dan hasil belajar

Hasil observasi tentang keaktifan siswa pada saat kegiatan pembelajaran berlangsung terlihat pada tabel 6 dan hasil evaluasi dari 39 orang siswa terlihat pada tabel 7 berikut.

\section{Tabel 6. Hasil observasi kegiatan siswa pada siklus II}

\begin{tabular}{|l|l|l|}
\hline No. & Aspek yang diamati & $\begin{array}{l}\% \text { Jumlah } \\
\text { siswa }\end{array}$ \\
\hline 1. & Antusias siswa dalam mengikuti KBM & 80 \\
2. & Kelancaran mengemukakan ide dalam memecahkan & 69 \\
\hline
\end{tabular}




\begin{tabular}{|l|l|l|}
\hline 3. & masalah & 70 \\
4. & Keaktifan siswa dalam diskusi & 82 \\
5. & Kemampuan siswa dalam menghimpun hasil diskusi & 80 \\
6. & Ketelitian dalam menghimpun hasil diskusi & 60 \\
7. & Keaktifan dalam bertanya & 67 \\
8. & Keaktifan siswa dalam mencari sumber belajar & 62 \\
& Kelancaran siswa dalam menjawab pertanyaan & \\
\hline
\end{tabular}

Tabel 7. Hasil evaluasi siswa pada siklus II

\begin{tabular}{|l|l|l|l|}
\hline No. & Nilai yang diperoleh & $\begin{array}{l}\text { Banyak } \\
\text { siswa }\end{array}$ & $\begin{array}{l}\text { Jumlah } \\
\text { nilai }\end{array}$ \\
\hline 1. & 85 & 2 & 170 \\
2. & 80 & 3 & 240 \\
3. & 78 & 3 & 234 \\
4. & 75 & 3 & 225 \\
5. & 70 & 2 & 140 \\
6. & 67 & 2 & 134 \\
7. & 65 & 3 & 195 \\
8. & 64 & 2 & 128 \\
9. & 63 & 5 & 315 \\
10. & 60 & 4 & 240 \\
11. & 50 & 3 & 150 \\
12. & 45 & 3 & 125 \\
13. & 40 & 4 & 160 \\
& & & \\
\hline & Jumlah siswa & 39 & \\
\cline { 2 - 4 } & Jumlah nilai & & 2456 \\
\cline { 2 - 4 } & Rata-rata nilai & & \\
\cline { 2 - 4 } & Banyak siswa yang tuntas & 25 & \\
\cline { 2 - 4 } & $\%$ ketuntasan & 64,10 & \\
\hline
\end{tabular}

Dari tabel 6 terlihat rata-rata nilai siswa naik menjadi 62,97, jumlah siswa yang tuntas belajar menjadi 25 orang dan ketuntasan secara klasikal menjadi $64,19 \%$.

3) Analisis dan Refleksi siklus II

Dari hasil observasi ditemukan beberapa hal, yaitu :

1. Ada beberapa siswa yang masih kurang aktif, baik dalam bertanya ataupun dalam menyelesaikan soal karena masih ada beberapa siswa yang kurang percaya diri untuk mengemukakan pendapat atau menanyakan masalah yang dihadapinya. 
2. Masih terdapat siswa yang kurang konsentrasi pada pemahaman konsep tapi terfokus untuk mencatat hasil dari teman sekelompoknya, karena beberapa siswa hanya berfikir untuk menyelesaikan soal tugas saja.

Dari hasil belajar siswa pada siklus II, model pembelajaran kooperatif tipe jigsaw sudah menunjukkan peningkatan hasil walaupun masih kurang memuaskan.

\section{Siklus III}

1) Pelaksanaan

Dengan melihat hasil observasi dan hasil evaluasi pada siklus II, maka halhal yang dilaksanakan pada siklus II adalah sebagai berikut :

1. Memberikan materi secara garis besar dan contoh sederhana.

2. Memberikan perhatian secara khusus kepada siswa yang mendapat hasil evaluasi pada siklus II kurang dari criteria ketuntasan minimum.

3. Memberikan motivasi secara kontiniu bagi siswa yang rasa percaya dirinya masih kurang untuk dapat bertanya dan memberikan pendapat dalam menyelesaikan masalah yang dihadapinya.

2) Hasil observasi dan hasil belajar

Dari 39 siswa dengan kehadiran $100 \%$, selama proses pembelajaran pada siklus III, hasil observasi tentang kegiatan belajar siswa terlihat pada tabel 8 dan hasil evaluasi siswa terlihat pada tabel 9 berikut:

Tabel 8 Hasil observasi kegiatan siswa pada siklus III

\begin{tabular}{|c|c|c|}
\hline No. & Aspek yang diamati & Persentase siswa \\
\hline 1. & Antusias siswa dalam mengikuti KBM & 87 \\
\hline 2. & Kelancaran mengemukakan ide dalam & 82 \\
\hline 3. & memecahkan masalah & 90 \\
\hline 4. & Keaktifan siswa dalam diskusi & 92 \\
\hline 5. & Kemampuan siswa dalam menghimpun hasil & 95 \\
\hline 6. & diskusi & 75 \\
\hline 7. & Ketelitian dalam menghimpun hasil diskusi & 83 \\
\hline 8. & Keaktifan dalam bertanya & 73 \\
\hline & Keaktifan siswa dalam mencari sumber belajar & \\
\hline & Kelancaran siswa dalam menjawab pertanyaan & \\
\hline
\end{tabular}


Tabel 9. Hasil evaluasi siswa pada siklus III

\begin{tabular}{|l|l|l|l|}
\hline No. & Nilai yang diperoleh & Banyak siswa & Jumlah nilai \\
\hline 1 & 2 & 3 & 4 \\
\hline 1. & 90 & 1 & 90 \\
2. & 88 & 2 & 176 \\
3. & 85 & 1 & 85 \\
4. & 84 & 2 & 168 \\
5. & 82 & 2 & 164 \\
6. & 80 & 3 & 240 \\
7. & 77 & 3 & 231 \\
8. & 75 & 5 & 375 \\
9. & 70 & 4 & 280 \\
10. & 68 & 4 & 272 \\
11 & 67 & 3 & 201 \\
12 & 63 & 4 & 252 \\
13 & 55 & 5 & 275 \\
\hline \multirow{5}{*}{} & Jumlah siswa & 39 & \\
\cline { 2 - 4 } & Jumlah Nilai & & 2809 \\
\cline { 2 - 4 } & Rata-rata nilai & 34 & \\
\cline { 2 - 4 } & Bnayak siswa yang tuntas & 87.17 & \\
\cline { 2 - 4 } & \% ketuntasan siswa & & \\
\hline
\end{tabular}

Dari tabel telihat bahwa hasil belajar yang diperoleh siswa cukup memuaskan dan persentase ketuntasan secara klasikal telah mencapai indikator keberhasilan. Dari 39 siswa, yang tuntas belajar 34 orang, persentase ketuntasan mencapai $87,18 \%$ dan rata-rata nilai secara klasikal naik menjadi 72,02\%.

3) Analisis dan refleksi

Dari penelitian di siklus III, ditemukan beberapa hal:

1. Proses pembelajaran sudah berjalan efektif, karena siswa sudah memahami model pembelajaran kooperatif tipe jigsaw.

2. Komunikasi di kelompok asal maupun di kelompok ahli sudah berjalan lancar, karena rasa percaya diri siswa tumbuh dan termotivasi untuk dapat menyelesaikan masalah.

3. Siswa tekun dalam menyelesaikan soal dan dapat terselesaikan dengan baik karena kerja sama di kelompok asal dan di kelompok ahli sudah berjalan dengan baik dan lancar.

Jumlah siswa yang tuntas belajar pada siklus III sebanyak 34 orang atau $87,18 \%$, dengan kata lain indicator keberhasilan pada PTK ini telah tercapai, 
dan tindakan penelitian diberhentikan. Hasil evaluasi belajar secara keseluruhan pada PTK ini terlihat pada tabel 10 berikut.

Tabel 10. Rekapitulasi hasil belajar siswa

\begin{tabular}{|l|l|l|l|l|l|}
\hline No. & $\begin{array}{l}\text { Kegiatan } \\
\text { pembelajaran }\end{array}$ & $\begin{array}{l}\text { Jumlah } \\
\text { siswa }\end{array}$ & $\begin{array}{l}\text { Jumlah } \\
\text { siswa yang } \\
\text { tuntas }\end{array}$ & $\begin{array}{l}\text { Nilai rata- } \\
\text { rata }\end{array}$ & $\begin{array}{l}\text { Persentase } \\
\text { ketuntasan }\end{array}$ \\
\hline 1. & Pra tindakan & 39 & 15 & 58,05 & 38,46 \\
\hline 2. & Siklus I & 39 & 14 & 58,15 & 35,89 \\
\hline 3. & Siklus II & 39 & 25 & 62,97 & 64,10 \\
\hline 4. & Siklus III & 39 & 34 & 72,02 & 87,18 \\
\hline
\end{tabular}

\section{Pembahasan}

Data yang diperoleh dari penelitian ini adalah sebagai berikut :

1. Pada pembelajaran pratindakan dengan menggunakan metode caramah dan

latihan, jumlah siswa yang tuntas belajar 15 porang $(38,46 \%)$ dari 39 siswa, rata-rata kelas 58,05.

2. Pada siklusa I siswa yang tuntas belajar menurun menjadi 14 orang $(35,89$ $\%)$, rata-rata kelas naik menjadi 58,15. Hal ini menunjukkan bahwa kegiatan pembelajaran pada siklus I belum terlaksana dengan baik.

3. Pada siklus II terjadi kenaikan jumlah siswa yang tuntas belajar menjadi 25 orang $(64,10 \%)$, rata-rata kelas juga meningkat menjadi 62,97. Pada kegiatan pembelajaran siklus II, model pembelajaran kooperatif tipe jigsaw yang diterapkan sudah menunjukkan hasil walaupun masih kurang optimal.

4. Pada siklus III, jumlah siswa yang tuntas belajar menjadi 34 orang $(87,18 \%)$ dan rata-rata kelas meningkat menjadi 72,02.

Kegiatan pembelajaran yang telah berjalan dengan lancar, sehingga hasil yang diperoleh pada siklus III memenuhi indikator keberhasilan dari penelitian ini dan penelitian tidak dilanjutkan pada siklus berikutnya. Gambaran ini membuktikan bahwa model pembelajaran kooperatif tipe jigsaw dapat meningkatkan hasil belajar siswa, baik kognitif, afektif atau psikomootor. 
Meningkatkan Hasil Belajar Siswa Pada Notasi Sigma Barisan

Dan Deret Melalui Model Pembelajaran Kooperatif Tipe Jigsaw

Di Kelas XII IPA I Sekolah Menengah Atas Negeri I Muaro Jambi

Peningkatan hasil belajar ini disebabkan karena penerapan model pembelajaran kooperatif tipe jigsaw dapat mendorong siswa untuk aktif dan saling membantu dalam menguasai materi pelajaran dalam mencapai prestasi yang maksimal.

Pada kegiatan pembelajaran pratindakan dengan menerapkan metode ceramah, latihan dan penugasan, hasil belajar yang dicapai siswa sangat rendah karena metode metode ceramah tidak dapat menciptakan siswa belajar aktif dan berdampak pada hasil belajar siswa yang tidak optimal. Pada siklus I, II dan III siswa berperan aktif untuk dapat menyelesaikan permasalahan sedangkan guru hanya sebagai fasilitator dan motivator. Dengan demikian model pembelajaran siswa dapat diterapkan pada pelajaran matematika, dengan melihat materi pokok, kondisi siswa dan waktu yang tersedia.

\section{Kesimpulan}

Berdasarkan hasil penelitian yang diperoleh dapat disimpulkan bahwa penerapan model pembelajaran kooperatif tipe jigsaw dapat meningkatkan hasil belajar siswa kelas XII IPA I SMA Negeri I Muaro Jambi. Namun dalam pelaksanaannya, materi pelajaran secara garis besar harus diberikan di setiap awal pertemuan dan pemberian motivasi secara kontiniu kepada siswa sepanjang pelaksanaan pembelajaran.

\section{Saran}

Pembelajaran kooperatif tipe jigsaw dapat meningkatkan aktivitas dan hasil belajar pada diri siswa baik secara individual maupun secara kelompok pada mata pelajaran matematika.

\section{Daftar Rujukan}

Alma, B. 2008. Guru profesional. Bandung: Alfabeta.

Aqib,Z dkk. 2008. Penelitian Tindakan Kelas Untuk Guru, SMP, SMA, SMK. Bandung:Yrama Widya.

Arends, M. 2003. Learning to Teach. Singapore: Mc. Graw-Hill Book Arikunto. 2005. Dasar-dasar Evaluasi Pendidikan. Jakarta: Bumi Aksara. Hamalik, O. 1983. Metode Belajar dan Kesulitan Belajar. Bandung: Tarsito. Isjoni . 2007. Cooperative Learning. Bandung: Alpha Beta. 
Jihad, A dan Haris, A.. 2008. Evaluasi Pembelajaran. Yogyakarta: Multi Presindo.

Robinson, A. 1988. Azas-azas Praktek. Jakarta: Bharata.

Slavin, R. 2005. Cooperative Learning Theory, Research and Practice. London: Allymand Bacon.

Sudjana, N. 1988. Dasar - dasar Proses Belajar Mengajar. Bandung: Sinar Baru Algesindo.

Suherman, E dan Winataputra, U.S. 1992., Strategi Belajar Mengajar Matematika. Jakarta: Rineka Cipta.

Usman, M. 1999. Menjadi Guru Profesional. Bandung: PT. Remaja Rosda Karya. 